\title{
Effect of Foliar Application of Yeast Extract and some of Amino Acids on Growth and Chemical Composition of Two Drum Sticks Species (Moringa oleifera and Moringa ovalifolia) \\ Abd El-Baset, M. M. \\ Vegetable and Floriculture Department, Faculty of Agriculture, Mansoura University,
} Mansoura city, Egypt.

mohanedgaber@yahoo.com

\begin{abstract}
An experiment was carried out variation the efficiency of yeast extract at 1,2 or $3 \mathrm{~g} / \mathrm{L}$ and amino acids at 1,2 or $3 \mathrm{~cm}^{3} / \mathrm{L}$ as a foliar application for each to improve vegetative growth and some of chemical content of pot moringa plants (two species) Moringa oleifera, and Moringa ovalifolia. Amino acids at $3 \mathrm{~cm}^{3} / \mathrm{L}$ was more effective than most of the other treatments for increasing plant height, leaf numbers, fresh and dry weights of plants, total chlorophyll and carotene of leaves and some chemical composition. Amino acids at $3 \mathrm{~cm}^{3} / \mathrm{L}$ as three foliar sprays at thirty days intervals improved vegetative growth and chemical content of moringa plants.
\end{abstract}

Keywords: drum sticks plants, moringa, yeast extract and amino acids

\section{INTRODUCTION}

Moringa species, family Moringaceae are a tropical trees, it is considered as a most useful trees of the world, almost every part of the tree can be used for food, or has some other beneficial properties. It is used as foliage and seed for livestock. All parts of the moringa tree are palatable by mankind (Jahn, 1988).

Many reports have appeared in mainstream scientific journals describing its nutritional and medicinal properties. Its utility as a non-food product has also been extensively described, lumber, charcoal, fencing, water clarification, lubricating oil.

Human health has received a great attention nowadays. It was documented that chemical fertilizers have a pollutant effect on the soil and plant, and in turn, on the human health. Recently, great attention has focused on the possibility of natural and safety substitution, i.e., yeast in order to improve plant growth, flowering, fruit setting and total yield of horticultural plants. Yeast as a natural bio-stimulant appeared to induce astonishment effect on development growth and yield of many crops $\quad$ (Martinez-Anoya et al., 1990)

Yeast contains many of amino acids, vitamins and growth substances as a protective agent, most of nutritional elements ( $\mathrm{Na}, \mathrm{Ca}, \mathrm{Fe}, \mathrm{K}, \mathrm{P}, \mathrm{S}, \mathrm{Mg}, \mathrm{Zn}$ and $\mathrm{Si}$ ) and consisted of cytokine as well as some organic compounds (Nagodawithana, 1991). It was also investigated for improving growth of some crops (Fathy et al., 2000).

Primary metabolites such as amino acids, building blocks in the synthesis of proteins, are involved in plant growth and development (Hounsome et al., 2008). Amino acids are a well-known bio stimulant which has positive effects on plant growth, yield and significantly mitigates the injuries caused by abiotic stresses (Kowalczyk and Zielony 2008). Saeed et al. (2005) on soybean found that treatments of amino acids significantly improved growth parameters of shoots and fresh weight as well as pod yield. Liu Xing-Quan et al. (2008) found that spraying of amino acids at $0.25 \mathrm{ml} / \mathrm{L}$ significantly increased vegetative growth expressed as plant height and dry weight of potato plant. Abo Sedera et al. (2010) revealed that spraying strawberry plants with amino acids (peptone) at 0.5 or $1.0 \mathrm{~g} / \mathrm{L}$ significantly increased total nitrogen, phosphorus and potassium in plant foliage as well as total yield, weight and vitamin C content of fruits compared to control treatment.

This research study was carried out to evaluate the effect of foliar applications of yeast extract and amino acids on growth and chemical composition of two pot plant species ( Moringa oleifera, and Moringa ovalifolia,) plants.

\section{MATERIALS AND METHODS}

A pot experiment was carried out at (Nursery of Ornamental Plants and Laboratory of the Vegetable and Ornamental Plants Department Faculty of Agric. Mansoura Univ. Egypt) during the two successive seasons of 2014 and 2015.

\section{Plant material}

Two species of (Moringa oleifera, and Moringa ovalifolia) seeds were obtained from Agriculture Research Center Ministry of Agriculture, Egypt. The seeds were soaked in water for $24 \mathrm{~h}$. before planting and seed decorticated planted in $25 \mathrm{~cm}^{2}$ pottery pots (3 seeds per pot). Each pot was filled with $8 \mathrm{~kg}$ from a mixture of sand and clay $1: 2(\mathrm{v} / \mathrm{v})$; planting date was $14^{\text {th }}$ April during the both seasons. After two weeks of complete germination, removed weak plants and added as a basal dose (1g/pot) NPK of compound fertilizer after planted a month and added every two weeks for all plants until 2-4 leaves $(15 \mathrm{~cm}$ height almost) appeared on each plant.

Experimental design:

The experimental treatments were arranged in a factorial experiment two factor (first Moringa species second foliar application) in randomize complete block design with three replicates, each replicate included three plants and experiment design included the interaction treatments were fourteen treatments in both seasons as yeast extract and amino acids were used as a foliar spray with concentrations of $0,1,2$ or $3(\mathrm{~g} / \mathrm{L}$ yeast and $\mathrm{cm}^{3} / \mathrm{L}$ amino acids) individually at 30 days interval. Both of the yeast extract and amino acids were conducted to the chemical analysis for knowing its contents, as shown in Table (1 and 2) Also, the relevant data of the soil analysis are presented in Table (3).

N.B. The N P K (20:20:20) compound fertilizer was added as a basal dose $(1 \mathrm{~g} / \mathrm{L})$ after planted a month and added every two weeks for all plants and each treatment consisted of 3 foliar sprays at 30 days interval. 
Table 1. Chemical analysis of yeast extract according to Khedr and Farid (2000)

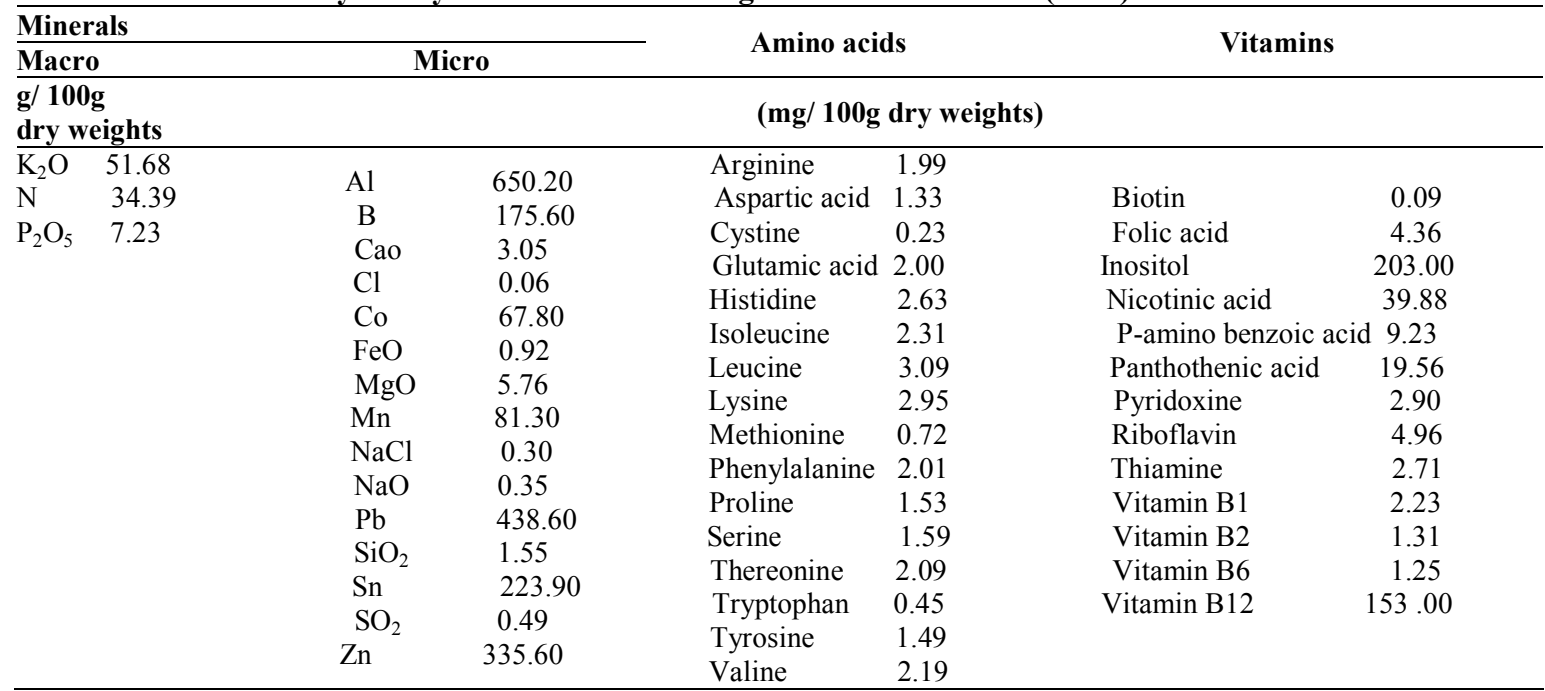

Table 2. Chemical analysis of amino acid according to Shafeek et al. (2016)

\begin{tabular}{|c|c|c|c|c|c|c|c|}
\hline Min & & & & cid & & Vits & \\
\hline$(\mathrm{g} / 1$ & & & $(\mathrm{m}$ & $\left.\mathrm{m}^{3}\right)$ & & $(\mathrm{mg} / 1$ & \\
\hline $\mathrm{Br}$ & 0.056 & Alanin & 100 & Lucine & 40 & Ascorbic & 1.00 \\
\hline $\mathrm{Ca}$ & 0.025 & Arginine & 20 & Methionine & 180 & B1 & 0.8 \\
\hline $\mathrm{Co}$ & 0.030 & Aspartic & 249 & Praline & 38 & $\mathrm{~B} 2$ & 2.4 \\
\hline $\mathrm{Cu}$ & 0.004 & Cysteine & 44 & Serine & 56 & B6 & 1.2 \\
\hline $\mathrm{Fe}$ & 1.500 & Histidine & 12 & Therionine & 38 & B12 & 0.82 \\
\hline $\mathrm{Mg}$ & 0.004 & Glutamic & 55 & Thiamine & 45 & Folic & 4.2 \\
\hline $\mathrm{Mn}$ & 0.500 & Glysine & 50 & Tryptophan & 20 & Niacine & 0.14 \\
\hline $\mathrm{S}$ & 0.010 & Isolucine & 52 & Valine & 68 & Pantothinic & 0.52 \\
\hline $\mathrm{Zn}$ & 2,000 & Lalanine & 22 & - & - & - & - \\
\hline
\end{tabular}

Table 3. Physical and chemical analysis of the soil .

\begin{tabular}{|c|c|c|c|}
\hline \multicolumn{2}{|l|}{ Mechanical a } & \multicolumn{2}{|l|}{ Chemical analysis } \\
\hline Coarse sand & 01.96 & & $\mathrm{~N} 42.00$ \\
\hline Fine sand & 29.33 & Available (ppm) & P 6.30 \\
\hline Silt & 37.03 & & K 330.00 \\
\hline \multirow[t]{2}{*}{ Clay } & 31.68 & Organic matter $(\%)$ & $\quad 1.83$ \\
\hline & & E.C.* $(\mathrm{dS} / \mathrm{m})$ & 1.8 \\
\hline \multirow[t]{2}{*}{ Texture } & Clay loamy & $\mathrm{pH}^{* *}$ & 8.14 \\
\hline & & $\mathrm{CaCO}_{3} \%$ & 1.95 \\
\hline \multicolumn{4}{|c|}{ Soluble (meq/100 g soil) } \\
\hline \multicolumn{2}{|l|}{ Cations } & \multicolumn{2}{|l|}{ Anions } \\
\hline $\mathrm{Ca}^{++}$ & 1.83 & $\mathrm{CO}_{3}=$ & 0.00 \\
\hline $\mathrm{Mg}^{++}$ & 1.27 & $\mathrm{HCO}_{3}^{-}$ & 2.53 \\
\hline $\mathrm{Na}^{+}$ & 0.97 & $\mathrm{SO}_{4}=$ & 0.74 \\
\hline $\mathrm{K}^{+}$ & 0.08 & $\mathrm{Cl}^{-}$ & 0.88 \\
\hline \multicolumn{3}{|c|}{$* 1: 5$ soil: water extract } & \\
\hline
\end{tabular}

\section{Data recorded:}

The harvest was done on August $15^{\text {th }}$ (after about

15 days from the last foliar spray) in both seasons.

1. Vegetative growth parameters:

1. Plant height $(\mathrm{cm})$.

2. Number of compound leaves (tri pinately)/plant.

3. Fresh and dry weights (g/plant).

2. Chemical determination analysis:

1. Nutrient elements determination from the dry plant samples:

-N\% determination:

Nitrogen \% was determined by modified micro Kjeldahle method as described by Pregl (1945).
-P (mg/100g) determination:

Phosphorus was determined according to Jackson (1967).

- K, Ca and Mg (mg/100g) determination:

Total K, Ca and $\mathrm{Mg}$ were estimated using atomic absorption spectrophotometer (A Perkin-Elmer, Model 2380.USA) according to the methods of Chapman and Pratt (1982).

2. Vitamin A, C (mg/100g), fat and total carbohydrates $\%$ determination from the dry plant samples:

-The content of vitamin A ( $\mathrm{mg} / \mathbf{1 0 0 g})$ determination:

This was determined Spectrophotometric ally using a modified standard method of AOAC (2000).

- The content of vitamin $\mathrm{C}(\mathrm{mg} / \mathbf{1 0 0 g})$ determination:

The content of vitamin $\mathrm{C}$ was determined titrimetrically using 2.6- dichlorphenolindophenol (AOAC, 1990).

- Crude Fat\% (Ether Extract)

The content of crude Fat $\%$ was determined according to (AOAC,2000).

-Total carbohydrates (d.w). :

Total carbohydrates were determined according to Hedge and Hofreiter (1962).

3. Pigments content total chlorophyll and carotenoids (mg/g f.w.) determination:

Total chlorophylls and carotenoids were determined in leaf samples $(\mathrm{mg} / \mathrm{g}$ fresh matter) according to Mackinney (1941). 


\section{Statistical analysis:}

The experimental design was a factorial experiment in randomize complete block design according to Steel and Torrie (1980). Data were subjected to the statistical analysis using Costat computer program. The treatments mean were compared using the least significant difference (LSD) at 0.05 level, as described by Gomez and Gomez (1984).

\section{RESULTS AND DISCUSSION}

Vegetative growth parameters:

\section{Plant height:}

Data in Table (4) also revealed these moringa plants examined materials were effective on improving growth. Treating Moringa oleifera, with amino acids at $3 \mathrm{~cm}^{3} / \mathrm{L}$ resulted in the highest significant increase in plant height in both seasons (158.66 and $131.33 \mathrm{~cm}$., respectively).In the both seasons, it was clearly indicated that plants treated with yeast $3 \mathrm{~g} / \mathrm{L}$, resulted in an increase in plant height values (147.00 and 107.33 $\mathrm{cm}$. respectively), but without significant differences compared to than amino acids at $3 \mathrm{~cm}^{3} / \mathrm{L}$. Data in the same Table revealed that there was no significant difference between using yeast extract and amino acids in both seasons, since the control gave lowest value in other species Moringa ovalifolia.

The increase may be related to the several functions of amino acids concerning the operation of protein structure of many plant enzymes needed for vegetative growth (Shafeek et al., 2012).

Identical conclusion recorded by AbdelMawgoud et al., 2011 found that, amino acids reflected the highest values for plant growth of legume plants.

Table 4. Effect of foliar applications of moringa plants on plant height, leaf number, fresh and dry weights at $2014\left(1^{\text {st }}\right)$ and $2015\left(2^{\text {nd }}\right)$ seasons.

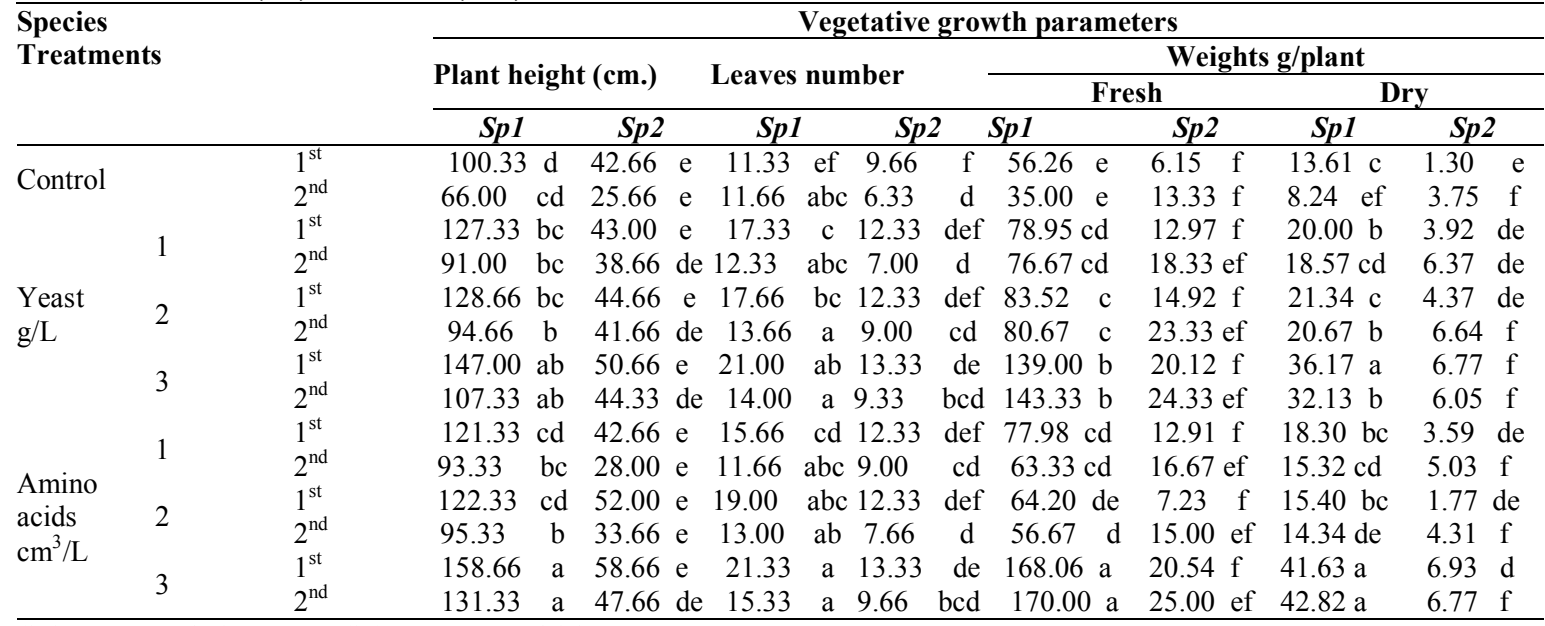

Sp1: Moringa oleifera. Sp2: Moringa ovalifolia.

Means having the same letter (s) in a column are not significant at $5 \%$ level

\section{Number of leaves/plant:}

Data in Table (4) showed that a wonderful number of leaves are increase in was achieved with $3 \mathrm{~cm}^{3} / \mathrm{L}$ amino acids ( 21.33 and 15.33 , respectively) in both seasons but when used yeast extract at $3 \mathrm{~g} / \mathrm{L}$ gave the leaves number (21.00 and 14.00 , respectively) without significant increasing in Moringa oleifera.

However, in both seasons Moringa ovalifolia, gave the same result obtained from the first species without significant differences in between.

The increase in number of leaves means good growth and quality.

The response of active dry yeast and chemical fertilization combination on vegetative growth was studied by many workers. Massoud (2006) on sage plants and Manoly and Nasr (2008) on gladiolus cv. Eurovision reported that the best vegetative growth was achieved when the plants were fertilized with active dry yeast plus chemical fertilization.

\section{Fresh and dry weight (g/plant):}

In Table (4) showed that treating plants with amino acids at $3 \mathrm{~cm}^{3} / \mathrm{L}$ significantly increased fresh and dry weights values in both seasons followed by yeast extract at $3 \mathrm{~g} / \mathrm{L}$, compared with 1 or $2 \mathrm{~g} / \mathrm{L}$
The increase of herb weight (either fresh or dry) means actually an increase in the metabolic contents such as carbohydrates, proteins etc. In addition this goes in parallel in general number of leaf mentioned in Table (4).

\section{Chemical determination analysis:}

\section{Nutrient elements determination:}

Minerals (N\%, P, K, Ca and Mg mg/100g DW):

Data in Table (5) showed that Moringa oleifera, treated with $3 \mathrm{~cm}^{3} / \mathrm{L}$ amino acids significantly increased the greatest $\mathrm{N} \%$ and $\mathrm{Ca} \mathrm{mg} / 100 \mathrm{~g}$ in both seasons than the two relatively lower used doses of amino acid.

It may be noticed that, amino acids can be used to partially to replace $\mathrm{NO}_{3}-$ or foliar spray in some plants. Generality, amino acids used led to decreased nitrate content and increased total nitrogen content in lettuce, onion, Chinese cabbage or other leafy crops, increase in plant height may be due to increase in total nitrogen (Wang et al.,2004). Some authors suggested that amino acids that preferred by some plants as sources of reduced nitrogen, and nitrate uptake was inhibited by amino acids. In fact, there was little evidence or data to support the conclusions. It has not been distinguished that increased total nitrogen came of nitrate or amino acids. 
In addition, using $3 \mathrm{~g} / \mathrm{L}$ yeast extract resulted in the highest significant increase in $\mathrm{N} \%$ and $\mathrm{Ca} \mathrm{mg} / 100 \mathrm{~g}$ than the two other examined doses of yeast extract. Moreover, there was significant differences between $3 \mathrm{~g} / \mathrm{L}$ yeast extract and those plants treated with $3 \mathrm{~cm}^{3} / \mathrm{L}$ amino acids in both seasons.

In other species Moringa ovalifolia, followed a similar trend as in the first one in content of $\mathrm{N} \%$ and $\mathrm{Ca}$ $\mathrm{mg} / 100 \mathrm{~g}$, while the best greatest significant increase in $\mathrm{P}, \mathrm{K}$ and $\mathrm{Mg} \mathrm{mg} / 100 \mathrm{~g}$ were found when Moringa ovalifolia., plants were treated with $3 \mathrm{~cm}^{3} / \mathrm{L}$ amino acids and $3 \mathrm{~g} / \mathrm{L}$ yeast extract with significant differences between them and exceed on Moringa oleifera.

2. Vitamin A, C, Fat and total carbohydrates \% determination:

Vitamin $A$ and $C$ (mg/100g DW):

In this concern data in Table (6) showed that all treatments increase vitamin $\mathrm{A}$ and $\mathrm{C}$ when compared to control, the maximum values of vitamin $\mathrm{A}$ and $\mathrm{C}$ resulted with foliar spray amino acids at $3 \mathrm{~cm}^{3} / \mathrm{L}(21.85$ and 103.39 in Moringa ovalifolia., and 19.29, 95.68 in Moringa oleifera, $\mathrm{mg} / 100 \mathrm{~g} \mathrm{DW}$, respectively), during the first season.

Data in the second season clearly indicated that it had almost the same trend observed in the first season.

Crude fat and carbohydrates (DW)\%:

Data preserved in Table (6) showed that crude fat and carbohydrates $\%$ in Moringa oleifera., were increased with treating plants by amino acids at $3 \mathrm{~cm}^{3} / \mathrm{L}$, since values were $3.26,5.13,39.10$ and $38.12 \%$ respectively, in the both seasons with a significant difference when compared with control.

Data in the Moringa ovalifolia, clearly indicated that it was nearly about the same trend as reported in the Moringa oleifera.

Table 5. Effect of foliar applications of moringa plants on mineral N\%, P, K, Ca and $\mathrm{Mg}(\mathrm{mg} / 100 \mathrm{~g})$ at 2014 $\left(1^{\text {st }}\right)$ and $2015\left(2^{\text {nd }}\right)$ seasons.

\begin{tabular}{|c|c|c|c|c|c|c|c|c|c|c|c|}
\hline \multirow{4}{*}{$\begin{array}{l}\text { Species } \\
\text { Treatments }\end{array}$} & & \multicolumn{10}{|c|}{ Chemical constituent parameters } \\
\hline & & \multirow{2}{*}{\multicolumn{2}{|c|}{ G/100g DW }} & \multicolumn{8}{|c|}{$\begin{array}{c}\text { Mg/100g DW } \\
\end{array}$} \\
\hline & & & & \multicolumn{2}{|c|}{$\mathbf{P}$} & \multicolumn{2}{|c|}{$\mathbf{K}$} & \multicolumn{2}{|c|}{$\mathbf{C a}$} & \multicolumn{2}{|c|}{$\mathbf{M g}$} \\
\hline & & $S p 1$ & $S p 2$ & $S p 1$ & $S p 2$ & Sp1 & $S p 2$ & Sp1 & $S p 2$ & $S p 1$ & $S p 2$ \\
\hline \multirow{2}{*}{ Control } & $1^{\text {st }}$ & $3.46 \mathrm{i}$ & $3.22 \mathrm{j}$ & $152.33 \mathrm{k}$ & $169.26 \mathrm{i}$ & $1118.66 \mathrm{~m}$ & 1146.001 & $1801.66 \mathrm{i}$ & 1710.331 & 296.861 & $321.06 \mathrm{j}$ \\
\hline & $2^{\text {nd }}$ & $3.21 \mathrm{j}$ & $3.04 \mathrm{i}$ & $163.63 \mathrm{~m}$ & $170.23 \mathrm{k}$ & $1176.66 \mathrm{n}$ & $1186.66 \mathrm{~m}$ & $1721.00 \mathrm{k}$ & $1648.00 \mathrm{n}$ & $321.60 \mathrm{n}$ & $353.66 \mathrm{i}$ \\
\hline \multirow{2}{*}{1} & $1^{\text {st }}$ & $3.60 \mathrm{~h}$ & $3.42 \mathrm{i}$ & $162.00 \mathrm{j}$ & $176.93 \mathrm{~h}$ & $1155.33 \mathrm{k}$ & $1182.33 \mathrm{j}$ & $1836.00 \mathrm{~g}$ & $1729.66 \mathrm{k}$ & $313.56 \mathrm{k}$ & $333.33 \mathrm{~h}$ \\
\hline & $2^{\text {nd }}$ & $3.40 \mathrm{~h}$ & $3.13 \mathrm{k}$ & 166.831 & $179.00 \mathrm{i}$ & 1194.661 & $1204.33 \mathrm{k}$ & $1771.33 \mathrm{i}$ & $1674.33 \mathrm{~m}$ & $328.30 \mathrm{~m}$ & $366.80 \mathrm{~g}$ \\
\hline \multirow{6}{*}{$\begin{array}{l}\text { Yeast } \\
g / L\end{array}$} & $1^{\text {st }}$ & $3.96 \mathrm{de}$ & $3.72 \mathrm{~g}$ & $183.86 \mathrm{~g}$ & $196.20 \mathrm{e}$ & $1236.00 \mathrm{~g}$ & $1262.66 \mathrm{f}$ & $1923.00 \mathrm{~d}$ & $1815.66 \mathrm{~h}$ & $341.03 \mathrm{~g}$ & $365.83 \mathrm{de}$ \\
\hline & $2^{\text {nd }}$ & $3.86 \mathrm{~d}$ & $3.52 \mathrm{~g}$ & $183.50 \mathrm{~h}$ & $194.66 \mathrm{e}$ & $1231.00 \mathrm{~h}$ & $1240.33 \mathrm{~g}$ & $1888.00 \mathrm{~d}$ & $1749.33 \mathrm{j}$ & $340.83 \mathrm{k}$ & $386.80 \mathrm{~d}$ \\
\hline & $1^{\text {st }}$ & $4.24 \mathrm{~b}$ & $3.94 \mathrm{e}$ & $198.10 \mathrm{e}$ & $216.36 \mathrm{~b}$ & $1294.00 \mathrm{~d}$ & $1323.00 \mathrm{~b}$ & $1977.33 \mathrm{~b}$ & $1872.00 \mathrm{f}$ & $362.33 \mathrm{e}$ & $390.83 \mathrm{~b}$ \\
\hline & $2^{\text {nd }}$ & $4.11 \mathrm{~b}$ & $3.76 \mathrm{e}$ & $194.40 \mathrm{e}$ & $208.60 \mathrm{~b}$ & $1267.33 d$ & $1284.33 \mathrm{~b}$ & $1941.00 \mathrm{~b}$ & $1821.33 \mathrm{~g}$ & $360.20 \mathrm{~h}$ & $402.10 \mathrm{~b}$ \\
\hline & $1^{\text {st }}$ & $3.77 \mathrm{fg}$ & $3.54 \mathrm{~h}$ & $174.16 \mathrm{~h}$ & $186.86 \mathrm{fg}$ & $1201.33 \mathrm{i}$ & $1227.66 \mathrm{~h}$ & $1876.33 \mathrm{f}$ & $1766.33 \mathrm{j}$ & $327.16 \mathrm{i}$ & $350.70 \mathrm{f}$ \\
\hline & $2^{\text {nd }}$ & $3.58 \mathrm{~g}$ & $3.31 \mathrm{i}$ & $174.56 \mathrm{j}$ & $187.33 \mathrm{~g}$ & $1213.66 \mathrm{j}$ & $1222.00 \mathrm{i}$ & $1847.33 \mathrm{f}$ & 1696.001 & 334.161 & $380.96 \mathrm{e}$ \\
\hline \multirow{4}{*}{$\begin{array}{l}\text { Amino acids } \\
\mathrm{cm}^{3} / \mathrm{L}\end{array}$} & $1^{\text {st }}$ & $4.13 \mathrm{c}$ & $3.83 \mathrm{f}$ & $189.96 \mathrm{f}$ & $208.43 \mathrm{c}$ & $1281.00 \mathrm{e}$ & $1291.33 \mathrm{~d}$ & $1965.66 \mathrm{c}$ & $1845.66 \mathrm{~g}$ & $354.63 \mathrm{f}$ & $379.83 \mathrm{c}$ \\
\hline & $2^{\text {nd }}$ & $4.02 \mathrm{c}$ & $3.66 \mathrm{f}$ & $190.50 \mathrm{f}$ & $203.26 \mathrm{c}$ & $1249.33 \mathrm{f}$ & $1259.33 \mathrm{e}$ & $1913.00 \mathrm{c}$ & $1796.66 \mathrm{~h}$ & $346.63 \mathrm{j}$ & $394.03 \mathrm{c}$ \\
\hline & $1^{\text {st }}$ & $4.32 \mathrm{a}$ & $4.02 \mathrm{~d}$ & $203.90 \mathrm{~d}$ & $224.23 \mathrm{a}$ & $1314.33 \mathrm{c}$ & $1347.33 \mathrm{a}$ & $2002.00 \mathrm{a}$ & $1903.00 \mathrm{e}$ & $370.80 \mathrm{~d}$ & $401.83 \mathrm{a}$ \\
\hline & $2^{\text {nd }}$ & $4.21 \mathrm{a}$ & $3.95 \mathrm{c}$ & $198.86 \mathrm{~d}$ & $212.80 \mathrm{a}$ & $1275.66 \mathrm{c}$ & $1299.00 \mathrm{a}$ & $1965.33 \mathrm{a}$ & $1869.66 \mathrm{e}$ & $374.83 \mathrm{f}$ & $411.10 \mathrm{a}$ \\
\hline
\end{tabular}

Sp1: Moringa oleifera.

Sp2: Moringa ovalifolia

Means having the same letter (s) in a column are not significant at $5 \%$ level

Table 6. Effect of foliar applications of moringa plants on Vitamin A and $\mathrm{C}$ (mg/100g), crude Fat and carbohydrates $(\%)$ at $2014\left(1^{\text {st }}\right)$ and $2015\left(2^{\text {nd }}\right)$ seasons.

\begin{tabular}{|c|c|c|c|c|c|c|c|c|c|c|}
\hline \multirow{4}{*}{$\begin{array}{l}\text { Species } \\
\text { Treatments }\end{array}$} & & & \multicolumn{8}{|c|}{ Chemical constituent parameters } \\
\hline & & & \multicolumn{4}{|c|}{ Vitamin (mg/100g) } & \multirow{2}{*}{\multicolumn{2}{|c|}{ Crude Fat(\%) }} & \multirow{2}{*}{\multicolumn{2}{|c|}{ Carbohydrates (\%) }} \\
\hline & & & \multicolumn{2}{|c|}{ A } & \multicolumn{2}{|c|}{$\mathbf{C}$} & & & & \\
\hline & & & Sp1 & Sp2 & Spl & Sp2 & Sp1 & Sp2 & Sp1 & Sp2 \\
\hline \multirow{4}{*}{ Control } & & $1^{\text {st }}$ & $16.37 \mathrm{j}$ & $18.54 \mathrm{fg}$ & $86.27 \mathrm{n}$ & $98.02 \mathrm{~g}$ & $2.25 \mathrm{~h}$ & $2.47 \mathrm{~g}$ & $35.64 \mathrm{~cd}$ & $35.40 \mathrm{~d}$ \\
\hline & & $2^{\text {nd }}$ & $17.31 \mathrm{~m}$ & $19.06 \mathrm{~h}$ & $16.97 \mathrm{n}$ & $18.65 \mathrm{i}$ & $2.10 \mathrm{~b}$ & $2.42 \mathrm{~b}$ & 34.511 & $34.20 \mathrm{~m}$ \\
\hline & \multirow{2}{*}{1} & $1^{\text {st }}$ & $16.98 \mathrm{ij}$ & 19.12 ef & $87.90 \mathrm{~m}$ & $99.10 \mathrm{f}$ & $2.32 \mathrm{~h}$ & $2.64 \mathrm{f}$ & $31.86 \mathrm{e}$ & $36.02 \mathrm{bcd}$ \\
\hline & & $2^{\text {nd }}$ & 17.961 & $19.67 \mathrm{f}$ & $17.27 \mathrm{~m}$ & $19.20 \mathrm{~g}$ & $2.17 \mathrm{~b}$ & $2.51 \mathrm{~b}$ & $33.94 \mathrm{n}$ & $35.16 \mathrm{j}$ \\
\hline \multirow{6}{*}{$\begin{array}{l}\text { Yeast } \\
\mathrm{g} / \mathrm{L}\end{array}$} & \multirow{2}{*}{2} & $1^{\text {st }}$ & $17.90 \mathrm{gh}$ & $20.32 \mathrm{~cd}$ & $91.12 \mathrm{k}$ & $101.15 \mathrm{~d}$ & $2.67 \mathrm{f}$ & $2.85 \mathrm{~d}$ & $36.73 \mathrm{abcd}$ & $37.12 \mathrm{abcd}$ \\
\hline & & $2^{\text {nd }}$ & $18.52 \mathrm{j}$ & $20.50 \mathrm{c}$ & $17.97 \mathrm{k}$ & $20.38 \mathrm{~d}$ & $2.58 \mathrm{~b}$ & $2.90 \mathrm{~b}$ & $35.86 \mathrm{~h}$ & $36.10 \mathrm{~g}$ \\
\hline & \multirow{2}{*}{3} & $1^{\text {st }}$ & $17.50 \mathrm{hi}$ & $21.42 \mathrm{ab}$ & $94.53 \mathrm{i}$ & $102.51 \mathrm{~b}$ & $2.90 \mathrm{~cd}$ & $2.97 \mathrm{c}$ & $38.31 \mathrm{ab}$ & $38.17 \mathrm{abc}$ \\
\hline & & $2^{\text {nd }}$ & $18.23 \mathrm{k}$ & $20.82 \mathrm{~b}$ & 17.631 & $21.08 \mathrm{~b}$ & $3.19 \mathrm{~b}$ & $3.37 \mathrm{~b}$ & $37.42 \mathrm{c}$ & $37.09 \mathrm{~d}$ \\
\hline & & $1^{\mathrm{st}}$ & $18.94 \mathrm{f}$ & $19.74 \mathrm{de}$ & 89.481 & $99.89 \mathrm{e}$ & $2.42 \mathrm{~g}$ & $2.76 \mathrm{e}$ & $36.01 \mathrm{bcd}$ & $36.58 \mathrm{abcd}$ \\
\hline & 1 & $2^{\text {nd }}$ & $19.41 \mathrm{~g}$ & $20.27 \mathrm{~d}$ & $18.98 \mathrm{~h}$ & $20.06 \mathrm{e}$ & $2.29 \mathrm{~b}$ & $2.79 \mathrm{~b}$ & $34.84 \mathrm{k}$ & $35.47 \mathrm{i}$ \\
\hline \multirow{4}{*}{$\begin{array}{l}\text { Amino acids } \\
\mathrm{cm}^{3} / \mathrm{L}\end{array}$} & \multirow{2}{*}{2} & $1^{\mathrm{st}}$ & $17.48 \mathrm{hi}$ & $20.96 \mathrm{bc}$ & $92.99 \mathrm{j}$ & $101.94 \mathrm{c}$ & $2.82 \mathrm{de}$ & $2.96 \mathrm{c}$ & $37.44 \mathrm{abcd}$ & $37.71 \mathrm{abcd}$ \\
\hline & & $2^{\text {nd }}$ & $18.78 \mathrm{i}$ & $20.74 \mathrm{~b}$ & $18.33 \mathrm{j}$ & $20.74 \mathrm{c}$ & $3.01 \mathrm{~b}$ & $3.28 \mathrm{~b}$ & $36.42 \mathrm{f}$ & 36.83 e \\
\hline & \multirow{2}{*}{3} & $1^{\mathrm{st}}$ & 19.29 ef & $21.85 \mathrm{a}$ & $95.68 \mathrm{~h}$ & $103.39 \mathrm{a}$ & $3.26 \mathrm{a}$ & $3.14 \mathrm{~b}$ & $39.10 \mathrm{a}$ & $38.48 \mathrm{ab}$ \\
\hline & & $2^{\text {nd }}$ & $19.98 \mathrm{e}$ & $21.06 \mathrm{a}$ & $19.72 \mathrm{f}$ & $21.42 \mathrm{a}$ & $5.13 \mathrm{a}$ & $3.50 \mathrm{~b}$ & $38.12 \mathrm{a}$ & $37.78 \mathrm{~b}$ \\
\hline
\end{tabular}


3. Pigments content (total chlorophyll and carotenoids): In this concern data presented in Table (7) revealed that Moringa oleifera. plants treated with the higher level of yeast extract at $3 \mathrm{~g} / \mathrm{L}$ significantly increased the total chlorophyll (34.03 and $34.89 \mathrm{mg} / \mathrm{g}$ FW) respectively, in both seasons than the two relatively lower used doses of yeast extract.

In the same Table data results that when used high concentration of amino acids gave the highest amount of total chlorophyll (28.77 and $28.31 \mathrm{mg} / \mathrm{g} \mathrm{FW}$ ) in both seasons but there was no significant difference between using yeast extract at $3 \mathrm{~g} / \mathrm{L}$ and $3 \mathrm{~cm}^{3} / \mathrm{L}$ of amino acids.In Moringa ovalifolia, reported that total chlorophyll was nearly about the same trend as in the type one.

The prop able plays a great role of carotenoids in plants with vitamin A manufacture. Recently two functions were discovered. The first one is protection against photo oxidation of chlorophyll. The second is transferring energy to chlorophyll A.

The increases noticed in carotenoids content as affected by yeast a spraying may be to attribute to the different enzymes, vitamins atc. Which the yeast a possess that have a response on photosynthesis process.

Data in the second seasons, clearly followed the same trend observed in the first season.

Table 7. Effect of foliar applications of moringa plants on Photosynthetic pigments (total chlorophyll and carotenoid (mg/ g FW) at $2014\left(1^{\text {st }}\right)$ and $2015\left(2^{\text {nd }}\right)$ seasons.

\begin{tabular}{|c|c|c|c|c|c|}
\hline \multirow{3}{*}{$\begin{array}{l}\text { Species } \\
\text { Treatments }\end{array}$} & & \multicolumn{4}{|c|}{ Photosynthetic pigments (mg $\backslash \mathrm{g}$ FW) } \\
\hline & & \multicolumn{2}{|c|}{ Total chlorophyll } & \multicolumn{2}{|c|}{ Carotene } \\
\hline & & $S p 1$ & $S p 2$ & Sp1 & $S p 2$ \\
\hline \multirow{2}{*}{ Control } & $1^{\mathrm{st}}$ & 27.84 abcd & $22.68 \mathrm{~d}$ & $7.96 \mathrm{c}$ & $7.76 \mathrm{~cd}$ \\
\hline & $2^{\text {nd }}$ & $30.57 \mathrm{abc}$ & $22.23 \mathrm{~d}$ & $8.11 \mathrm{c}$ & $7.92 \mathrm{c}$ \\
\hline \multirow{6}{*}{ Yeast g/L } & $1^{\mathrm{st}}$ & $30.03 \mathrm{ab}$ & $26.48 \mathrm{bcd}$ & $9.74 \mathrm{a}$ & $7.89 \mathrm{~b}$ \\
\hline & $2^{\text {nd }}$ & $34.04 \mathrm{a}$ & $26.20 \mathrm{bcd}$ & $10.00 \mathrm{ab}$ & $7.88 \mathrm{~cd}$ \\
\hline & $1^{\mathrm{st}}$ & $29.58 \mathrm{abc}$ & $26.04 \mathrm{bcd}$ & $9.72 \mathrm{a}$ & $9.20 \mathrm{ab}$ \\
\hline & $2^{\text {nd }}$ & $31.25 \mathrm{ab}$ & $26.35 \mathrm{bcd}$ & $9.75 \mathrm{~b}$ & $7.81 \mathrm{~cd}$ \\
\hline & $1^{\text {st }}$ & $34.03 \mathrm{a}$ & $27.47 \mathrm{abcd}$ & $10.01 \mathrm{a}$ & $9.08 \mathrm{ab}$ \\
\hline & $2^{\text {nd }}$ & $34.89 \mathrm{a}$ & $27.67 \mathrm{abcd}$ & $10.55 \mathrm{a}$ & $9.23 \mathrm{ab}$ \\
\hline \multirow{2}{*}{ Amino acids $\mathrm{cm}^{3} / 1 / 1$} & $1^{\text {st }}$ & $27.11 \mathrm{bcd}$ & $24.83 \mathrm{bcd}$ & $9.69 \mathrm{a}$ & $8.84 \mathrm{ab}$ \\
\hline & $2^{\text {nd }}$ & $30.22 \mathrm{abc}$ & $24.83 \mathrm{bcd}$ & $8.10 \mathrm{c}$ & $7.72 \mathrm{~cd}$ \\
\hline & $1^{\text {st }}$ & $27.03 \mathrm{bcd}$ & $22.77 \mathrm{~cd}$ & $9.34 \mathrm{ab}$ & $8.74 \mathrm{ab}$ \\
\hline & $2^{\text {nd }}$ & $26.99 \mathrm{bcd}$ & $23.29 \mathrm{~cd}$ & $8.06 \mathrm{c}$ & $7.70 \mathrm{~cd}$ \\
\hline & $1^{\mathrm{st}}$ & $28.77 \mathrm{abcd}$ & $25.61 \mathrm{bcd}$ & $9.33 \mathrm{ab}$ & $9.21 \mathrm{ab}$ \\
\hline & $2^{\text {nd }}$ & $28.31 \mathrm{abcd}$ & $25.62 \mathrm{bcd}$ & $9.69 \mathrm{a}$ & $7.26 \mathrm{~d}$ \\
\hline
\end{tabular}

Sp1: Moringa oleifera.

Sp2: Moringa ovalifolia.

Means having the same letter (s) in a column are not significant at $5 \%$ level

\section{DISCUSSION}

The plant can use the amino acids in different signaling pathways according to their stage of development. This may be due to the cause why amino acids responses, with the exception of glycine amino acids are significant components of antioxidant systems in plants. The action of these molecules involves the reduction of and free radicals and osmoprotection (Rennenberg and Herschbach, 2014). On the other hand, glycine is also involved in the route of glyoxylate production, a compound that can reduce $\mathrm{H}_{2} \mathrm{O}_{2}$ content in plants, leading to the reduction of LP (Alhasawi et al.,2015). Generally, glyoxylate can produce NADPH and ATP, energy molecules used in various metabolic processes.

The execution of amino acids can directly increase or indirectly signaling the production of glycine, which acts on the signaling mechanism of the antioxidant and protection system, increasing the vitality of the enzymes.

\section{General conclusions:}

The increments in moringa plants growth measurements under the foliar application of yeast extract and amino acids might be attributed to the multiple advantages of foliar spraying methods such as rapid and efficient response to the plant needs, and independence of soil condition. It is due to the foliar yeast extract and amino acids fertilization during plant growth which can improve the mineral status of plants and increase the vigor of plant. The main reason for that vigoristy of moringa due the yeast extract and amino acids foliar application compared to the other foliar treatments might be due to the yeast extract and amino acids contain the most major nutritional element. Amino acids application play a great role in increasing the metabolism processing due to the importance of building protein, carbohydrates and fats in the plant tissues. Consequently amino acids as foliar application gained a promotion in vegetative plant growth i.e plant height, leaf numbers, fresh and dry weight of plants, pigments content of leaves and chemical composition of whole moringa plants and its different organs.

It could be concluded that, foliar application of amino acids at $3 \mathrm{~cm}^{3} / \mathrm{L}$ resulted in the plant height, leaf numbers, fresh and dry weight of plants, pigments content of leaves and chemical composition, followed by plants supplied by active dry yeast at $3 \mathrm{~g} / \mathrm{L}$.

Conclusion

The obtained results from the present research indicated that foliar application of amino acid and yeast extract, at suitable concentrations, had positive effects on the growth and the content of secondary metabolites, antioxidants and antioxidant activity. 
The stimulated values of biochemical constituents strengthened the role of the applied amino acids in the metabolism of moringa plants.

Our results indicated that amino acids and yeast extract application in organic farming can be used to increasing the fertilizer use efficiency similar to mineral fertilizer usage. In view of environmental pollution in case of excessive use of mineral fertilizers and due to high costs in the production of $\mathrm{N}$ fertilizers, biofertilizers tested in our study may well be suited to achieve sustainable and ecological agricultural production in the region. An important nutritional problem of developing countries is micro

-nutrient malnutrition. Moringa plants can be grown better with high yield and quality in soils amended with $100 \%$ of the recommended dose of $\mathrm{N}, \mathrm{P}$ and $\mathrm{K}$ as mineral fertilizers and amino acids at $3 \mathrm{~cm}^{3} / \mathrm{L}$ as three foliar sprays at thirty days intervals to improved vegetative growth and chemical content of moringa plants.

This article associate the view that amino acids have some possible to increase use efficiency of conventional fertilizer in traditional farming.

\section{REFERENCES}

Abdel-Mawgoud, A.M.R.; El-Bassiouny, A.M.; Ghoname, A. and Abou-Hussein, S.D. (2011). Foliar application of amino acids and micronutrients enhance performance of green bean crop under newly reclaimed land conditions. Aust. J. Basic Appl. Sci., 5(6): 51-55.

Abo Sedera, F. A.; Abd El Latif, A. A.; Bader, L.A.A. and Rezk , S.M. (2010).Effect of NPK mineral fertilizer levels and foliar application with humic and amino acids on yield and quality of strawberry. Egyp.J. of Appl. Sci., 25:154-169.

Alhasawi, A.; Castonguay, Z.; Appanna, N.D.; Auger, C.; and Appanna,V.D.(2015).Glycine metabolism and anti-oxidative defense mechanisms in Pseudomonas fluorescens. Microbiol. Res., 171: 26-31.

AOAC.(1990).Official methods of analysis of the Association of Official Analytical Chemists. Fifteen edition. Arlington VA, Association of Official Analytical Chemists, 1058-1059.

AOAC.(2000). Association of Official Analytical Chemists, 17th Ed. of A.O.A.C. international published by A.O.A.C. international Maryland, U.S.A., 1250pp.

Chapman, H. D., and Pratt, F. P. (1982). Determination of minerals by titration method. Methods of Analysis for Soils, Plants and Water, 2nd edn. Oakland, CA: Agriculture Division, California University, 169-170

Fathy, E.S.L.; Farid, S. and El-Desouky S. A.(2000). Induce cold tolerance of outdoor tomatoes during early summer season by using triphosphate (ATP), yeast, other natural and chemical treatments to impove their fruiting and yield. J. Agric. Sci. Mansoura Univ., 25 (1):377-401.
Gomez, K.A. and Gomez A.A.(1984).Statistical Procedures. Agric. Res. 2nd Ed. Johnwiley and Sons, Inc, New York, USA.

Hedge, J.E.and Hofreiter, B.T.(1962).Carbohydrate Chemistry, Whistler R. L.; Be Miller. J. N. (Eds.) Academic. Press New York. 17-22.

Hounsome, N.; Hounsome, B.; Tomos, D. and EdwardsJones G. (2008). Plant metabolites and nutritional quality of vegetables. J Food Sci., 73(4): 48-65

Jackson, M.L.(1967).“ Soil Chemical Analysis advanced course" Puble, by the auther, Dept. of Soils, Wise Univ., Madison 6, Wischensen, U.S.A

Jahn, S.A.A.(1988). Using Moringa Seeds as Coagulants in Developing Countries. J. Awwa (Mangement Operations): 43-50.

Khedr, Z. and Farid, S.(2000).Response of naturally virus infected tomato plants to yeast extract and phosphoric acid application. Annals Agric. Sci. Moshtohor, 38(2): 927-939.

Kowalczyk, K. and Zielony T.(2008). Effect of Amino plant and Asahi on yield and quality of lettuce grown on rockwool.Conf.of biostimulators in modern agriculture, 7-8 Febuary, Warsaw, Poland.

Liu Xing Q.; Chen H.Y.; Qin-Xue N. and Seung L.K.(2008). Evaluation of the role of mixed amino acids in nitrate uptake and as simulation in leafy radish by using 15 n-labeled nitrate. Agric. Sci. CHN., 7(10):1196-1202.

Mackinney, G. (1941). Absorpation of light by cholorphyll solution. J. Bio. Chem., 140:315332.

Manoly, N. D. and Nasr A. A.(2008). Response of Eurovision Gladiolus cultivar plants to rock phosphate and yeast. J. Agric. Sci. Mansoura Univ., 33 (12):8809-8821.

Martinez-Anoya, M. A.; Pitarch, B.; Bayarri, P. and Beneditode Barber, C.(1990).Microflora of the sour doughs wheat flour bread interaction between yeast and lactic acid bacteria in wheat doughs and their effects on bread quality. Cereal Chem., 6: 85

Massoud, H.Y.(2006).Effect of phosphorus fertilization levels and foliar application with active dry yeast bio-fertilizer on growth, herb yield, essential oil productivity and chemical components of sage (Salvia officinalis L.). J. Sci. Mansoura Univ., 31 (10): 6649-6665.

Nagodawithana, W.T.(1991).Yeast technology. Foods Corporation Pup. By Van Nostrand Reinhold New York, USA. P. 273.

Pregl, F.(1945).“Quantitative Organic Microanalysis 4th.” Ed. I. Chudrial, London.

Rennenberg, H. and Herschbach, C.(2014). A detailed view on sulphur metabolism at the cellular and whole-plant level illustrates challenges in metabolite flux analyses. J. Exp. Bot., 65: 57115724. 
Saeed M.R.; Kheir A.M. and Al-Sayed A.A.(2005). Supperssive effect of some amino acids against Meloidogyne incognita on soya beans.J. Agric. Sci. Mansoura Univ., 30 (2): 1097 - 1103.

Shafeek, M.R.; Magda M.; Hafez A.; Aisha H. and Asmaa R. Mahmoud (2016). Effectiveness of Foliar Enforcement by Amino Acids and Bio Potassium Fertilizer on Growth, Yield and Bulb Goodness of Garlic Plants Under Latterly Reformed Soil. Res. J. of Pharmaceutical, Biological and Chemical Sciences, 7(5):836-844.

Shafeek, M.R.; Helmy, Y.I. ; Magda, A.F. Shalaby and Nadia, M. Omer, (2012). Response of onion plants to foliar application of sources and levels of some amino acids under sandy soil conditions. Journal of Applied Sci. Res., 8(11): 5521-5527.
Steel, R.G.D. and Torrie G.H.(1980). Principles and Procedures of Statistics, 2nd Ed. McGraw-Hill, book Co. Inc. New York, U.S.A. pp.633

Wang H.; Wu L. and Tao Q.(2004). Influence of partial replacement of nitrate by amino acids on nitrate accumulation of pakchoi (Brassica chinensis L.). China Environ. Sci., 24: 19-23.

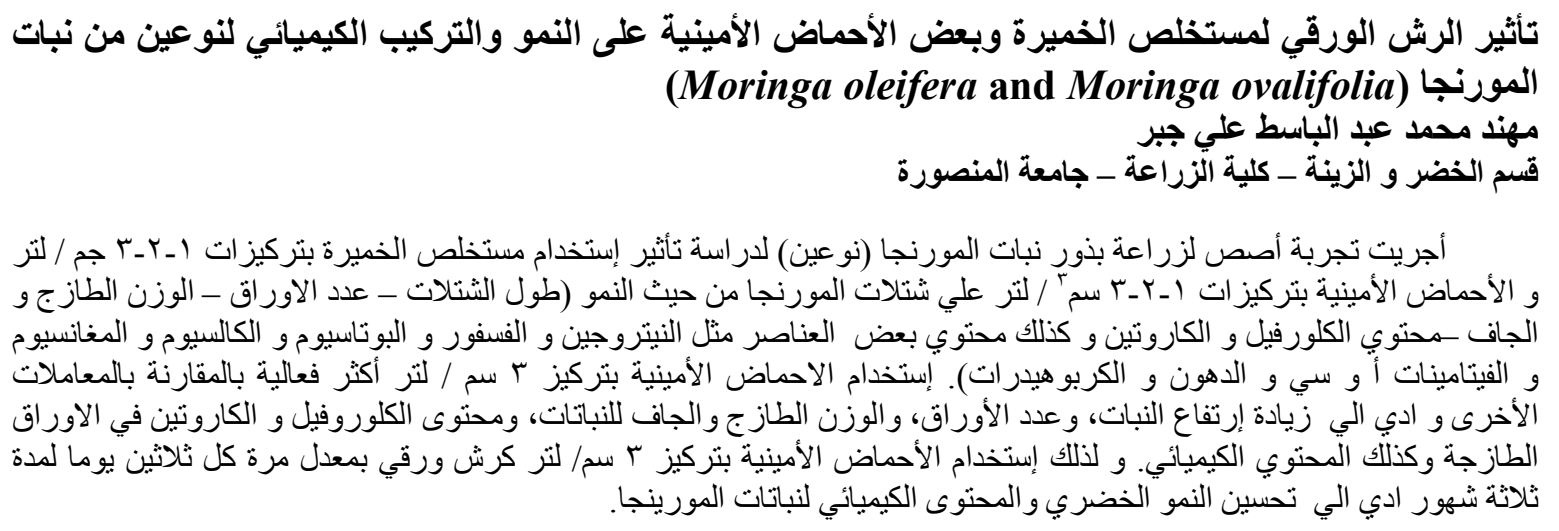

